\title{
VARIA
}

Maja Pawłowska

maja.pawlowska@uwr.edu.pl

orcid.org/ 0000-0002-2024-2715

Uniwersytet Wrocławski

Instytut Filologii Romańskiej

pl. Bp. Nankiera 4

50-140 Wrocław

\section{Pomiędzy występkiem a cnotą: trudna droga człowieka światowego w powieści Jean-Pierre Camusa Palombe ou la femme honorable}

Between Vice and Virtue:

The Mondain's Difficult Path in Jean-Pierre Camus' Palombe, ou la femme honorable

Summary: Published in 1625, Palombe, ou la femme honorable, is a novel by Jean-Pierre Camus showing the model of a mondain, or worldly, Christian. With the example of count Fulgent, an immoral rake, who undergoes a spiritual transformation, Camus demonstrates that even a libertine courtesan can become a good Christian. However, such coexistence is possible only for those who have achieved spiritual maturity and who can distinguish vice from virtue, consciously renouncing immorality. Camus represents the marriage of mondains not as a source of pleasure or opportunity for a libertine lifestyle, but rather as a contract demanding certain commitments and renouncements. On entering marriage, Fulgent is not initially morally prepared for the social position and responsibilities that he must assume. He only becomes a good husband and Christian once he accepts the commitments of his social position, This is indeed how Camus defines virtue: as a conscious renouncement of licentiousness and a conscious acceptance of duties imposed by society. To turn back from the path of debauchery is a slow and difficult process, just as it is to learn to fulfil one's moral duties. 
Keywords: Jean-Pierre Camus, roman dévot (pious romance), Palombe, ou la femme honorable, libertinage, French $17^{\text {th }}$ century novel

Streszczenie: Palombe, ou la femme honorable to opublikowana w 1625 r. powieść Jean-Pierre Camusa, w której autor przedstawił model chrześcijanina światowca (mondain). Na przykładzie głównego bohatera, rozwiązłego hrabiego Fulgencia, Camus ukazuje, że nawet libertyn może stać się dobrym chrześcijaninem. Możliwość ta jest jednak dostępna dla osób dojrzałych psychicznie, które potrafią odróżnić występek od cnoty i świadomie z niego zrezygnować. Małżeństwo mondains nie powinno polegać na poszukiwaniu uciech i rozwiązłym trybie życia. Stanowi rodzaj kontraktu, wymagającego wyrzeczeń. Fulgencio nie jest do niego psychicznie przygotowany i dlatego cierpi, gdy po ślubie musi starać się być wierny żonie. Stanie się dobrym chrześcijaninem i mężem dopiero, gdy zrozumie, jakich wyrzeczeń wymaga jego eksponowana pozycja społeczna. Pozbywanie się libertyńskich nawyków to powolny proces, podobnie jak dojrzewanie do wypełniania obowiązków.

Słowa kluczowe: Jean-Pierre Camus, powieść pobożna, Palombe, ou la femme honorable, libertynizm, XVII-wieczna powieść francuska

Jean-Pierre Camus, biskup Belley (1584-1652), należy do najwybitniejszych XVII-wiecznych pisarzy francuskich. Jego liczne romanse, zaliczane do gatunku tzw. powieści pobożnej, ukazywały się w latach 1620-16441. Wpisują się w nurt idei posttrydenckich, stawiających sobie za cel zahamowanie postępującej reformacji i umacnianie wiary katolickiej poprzez edukację ${ }^{2}$. Duchowy mentor i bliski przyjaciel Camusa, Franciszek Salezy, w wydanej w 1609 r. Introduction à la vie dévote (Wprowadzenie do życia pobożnego) ${ }^{3}$ wysunął pogląd, iż nie ma sprzeczno-

1 W tym okresie Camus opublikował ok. 70 powieści i prawie 200 nowel. Ponadto od 1608 r. aż do śmierci pisał traktaty teologiczne. Pełną listę utworów Camusa można znaleźć w monografii S. Robic-de Baecque, Le Salut par l'excès. Jean-Pierre Camus (1584-1652), la poétique d'un évêque romancier, Champion, Paris 1999, s. 421-425.

2 Głównym celem odbywających się w latach 1545-1563 posiedzeń Soboru Trydenckiego było zreformowanie Kościoła Katolickiego i jego strategii głoszenia wiary tak, by skutecznie powstrzymać odpływ wiernych do obozu protestantów. We Francji, podobnie jak w innych krajach europejskich, stworzono nowoczesne kolegia jezuickie, w których młodzież męska otrzymywała wszechstronne, katolickie wykształcenie, prowadzone według starannie opracowanego planu nauczania (tzw. Ratio studiorum). Zob. D. Bertrand, Pourquoi et comment les jésuites ont pris en charge l'enseignement en Europe, w: B. Pinchard, P. Servet (red.), Education, transmission, rénovation à la Renaissance, Droz, Genève 2006, s. 151-166. 
ści między życiem światowym a dążeniem do zbawienia. Według słów Camusa, to właśnie Franciszek Salezy namówił go, by zawracał z drogi grzechu osoby ze środowiska mondains („światowców”, czyli dworzan i elitę paryską), pisząc dla nich powieści pobożne ${ }^{4}$, łączące tradycyjną topikę powieściową z moralizatorskim przesłaniem ${ }^{5}$. Wybór utworów fikcjonalnych jako narzędzia skutecznej ewangelizacji wynikał m.in. z tego, że na początku w XVII w. romanse oraz piśmiennictwo religijne nie miały jasno określonych cech gatunkowych, niejednokrotnie dzieliły wspólne obszary tematyczne i formalne ${ }^{6}$. Romans „hybrydowy” nie wydawał się więc czytelnikom tworem sztucznym, a jego perswazja, dyskretnie wplatająca się w fabułę, była skuteczna.

Badacze społeczeństwa francuskiego omawianego okresu, np. Maurice Magendie w monografii La politesse mondaine (Uprzejmość światowców) ${ }^{7}$, wskazują, że cechą mondains było głębokie przeświadczenie o wyższości w stosunku do innych klas społecznych i związane z tym buta, arogancja oraz łamanie ogólnie przyjętych norm zachowań ${ }^{8}$. Natomiast na dworze królewskim, wśród osób równych stanem, życie arystokracji upływało pod znakiem nieustannej rywalizacji o zaszczyty i godności. Bezwzględnie dążono do umacniania pozycji rodu i powiększenia wpływów poprzez korzystne alianse, sojusze, intrygi i rozmaite manipulacje. Dominantą zachowania dworzan było umiejętne uwodzenie otoczenia, przekonywanie towarzystwa o swoich walorach, zyskiwanie sympatii. Pochodną tej taktyki było ożywione życie erotyczne obu płci, połączone z powszechnym tolerowaniem związków pozamałżeńskich, przy zachowaniu pozorów wierności?.

Biskup Belley, sam pochodzący z wysokiego rodu, bywalec dworu Henryka IV i Ludwika XIII ${ }^{10}$, świadomy nagannego stylu życia mondains oraz tego, że najczęściej byli oni słabo wykształceni ${ }^{11}$ i stronili od lektury wymagających intelektualnie

4 Zob. A. Pessel, L'«Essay sceptique» de Jean-Pierre Camus, „Les Études Philosophiques” 2008, nr 85, s. 187.

5 Por. M. Lever, Au seuil du XVIIe siècle, „Littératures Classiques” 1991, nr 15, s. 10. Romanse Camusa obfitują w motywy lubiane przez ówczesnych czytelników, takie jak: miłość od pierwszego wejrzenia, porwania, napady rozbójników/piratów, rozdzielenie zakochanych przez rodziców/opiekunów, choroba spowodowana miłosną tęsknotą czy też knowania zazdrosnego rywala/rywalki.

6 Temat ten rozwija szczegółowo S. Robic-de Baecque w artykule Romans et dévotion au XVIle siècle, „Littératures Classiques" 2000, nr 39, s. 33.

7 M. Magendie, La politesse mondaine et les théories de l'honnêteté, en France au XVIle siècle, de 1600 à 1660 , t. 1, Slatkine reprints, Genève 1993.

8 M. Magendie (op. cit., s. 64) opisuje przypadek marszałka de Luxembourg, który rzucił się z nożem na prawnika za to, że jego zdaniem zbyt opieszale zajmował się sprawą.

9 Ibidem, rozdz. V-VI.

10 Przez krótki okres w młodości Jean-Pierre Camus był paziem króla Henryka IV. Na dwór Ludwika XIII wielokrotnie był wzywany przez kardynała de Richelieu. Zob. S. Robic-de Baecque, op. cit., s. 22.

11 Sam król Ludwik XIII miał „naturalną awersję do nauki” (M. Magendie, op. cit., s. 17), a dworzan cechowała "głęboka ignorancja” (ibidem, s. 51-54). Jednym z powodów niedouczenia środowisk dworskich był krótki okres nauki w kolegium, niejednokrotnie młodzieńcy z wysokich rodów wchodzili w życie "dorosłe" 
traktatów czy kazań, postanowił nawracać ich na drogę cnoty, przemycając pożądane treści w romansach. Pisarz ukazywał, w jaki sposób powinni się zmienić, aby po śmierci dostąpić zbawienia ${ }^{12}$. Zdawał sobie sprawę z iluzoryczności proponowania temu specyficznemu środowisku rozwiązań wiążących się z drastyczną zmianą trybu życia i całkowitym przewartościowaniem priorytetów. Dlatego, bardziej pragmatycznie, podał wskazówki ułatwiające postępowanie w momentach trudnych, w których łatwo o zwątpienie i kryzys wiary. Ewangelizacja poprzez lekturę romansów była przedsięwzięciem nietypowym, zwłaszcza że był to gatunek, który ówcześni krytycy traktowali jako podrzędny ${ }^{13}$. Jednak był to zabieg skuteczny w przypadku mondains tradycyjne kazania odnosiły mierny skutek, słuchano ich niechętnie, natomiast romanse czytywano z upodobaniem.

W 1625 r. ukazała się Palombe, ou la femme honorable (Palombe, czyli kobieta uczciwa ${ }^{14}$, historia młodego hiszpańskiego libertyna i jego małżeństwa. Camus znat środowisko mondains zarówno od zewnątrz, jako obserwator zachowań ludzkich, jak i od wewnątrz, jako spowiednik dworzan. Miał więc wgląd w ukryte motywy postępowań, poznawał skrywane namiętności i porywy serca. Dzięki temu portret głównego bohatera nie jest sztuczny ani szablonowy, odbija rzeczywiste rozterki moralne arystokracji francuskiej lat 20 . XVII w. Pisarz stworzył postać prawdopodobną: wielowymiarową, budzącą zainteresowanie, zmuszającą do refleksji. Nakreślił historię młodego człowieka, który przebywa długą drogę od rozwiązłego libertyna do wiernego męża, przy czym jego metanoja mieści się w granicach wiarygodności.

Akcja powieści toczy się w Hiszpanii (osoby sięgające po romans oczekiwały egzotyki), jednak opisywane zachowania i stosunki są typowe dla ówczesnej Francji. Camus pisze o tym we wstępie: „historia ta została stworzona jako zwierciadło, w której dusze światowców mogą ujrzeć swe przywary oraz obowiązki"15. Główny bohater otrzymuje imię Fulgencio (czyli z łaciny „błyszczący, skrzący się”), które

bardzo wcześnie. Jeden z najwybitniejszych francuskich generałów, Henri de la Tour d’Auvergne, wicehrabia Turenne, dowodził wojskiem już w wieku 13 lat. Zob. R. Mousnier, Etudes sur la population de la France au XVIle siècle, „Le XVII' siècle” 1952, nr 16, s. 533.

12 Na ten aspekt twórczości Camusa zwracali uwagę XVII-wieczni krytycy francuscy, w tym Charles Perrault w biografii pisarza, którą umieścił w antologii wybitnych ludzi pióra (C. Perrault, Les Hommes illustres qui ont paru en France pendant ce siècle, M. Rogguet, La Haye 1698, s. 23-28).

13 W owym okresie we Francji implementowano Arystotelesowską hierarchię gatunków literackich, zgodnie z którą największym uznaniem cieszyła się epopeja, po niej następowała tragedia, a romans był gatunkiem ocenianym tak nisko, że w ogóle nie był brany pod uwagę. Uważano, że demoralizuje czytelników, rozbudzając ich wyobraźnię opisem grzesznych namiętności. Zob. M. Pawłowska, Mimesis a teorie siedemnastowiecznej powieści francuskiej, Wydawnictwo Uniwersytetu Wrocławskiego, Wrocław 2011, s. 17-20.

14 J.-P. Camus, Palombe, ou la femme honorable, Histoire catalane, C. Chappelet, Paris 1625.

15 J.-P. Camus, Palombe, op. cit., s. 6. Tłumaczenie tego cytatu oraz następnych własne (M.P.). We wszystkich kolejnych cytatach pochodzących z tej powieści ograniczę się do podawania w nawiasie numerów stron. 
podkreśla zarazem „świetność jego rodu” (s. 2), jak i fakt, że libertynizm nie jest domeną osób wywodzących się z bocznych gałęzi arystokracji, bez perspektyw, nie mogących w inny sposób dać upustu energii życiowej. Kreśląc portret Fulgencia, pisarz wymienia cechy mające istotne znaczenie dla czytelników mondains: jego szlachetne pochodzenie, dokonania i znacznie przodków, bogactwo oraz opinię, jaką cieszy się w towarzystwie. Wygląd fizyczny, jako nieistotny, został pominięty. Camus przedstawia również bardzo skrótowo życiorys tego dziecięcia wysokiego rodu, od najmłodszych lat wychowującego się w pałacu królewskim w Madrycie. Najpierw służył jako paź, następnie już jako młody dworzanin przez kilka lat zawierał przyjaźnie, ugruntowywał pozycję towarzyską. Pomagały mu w tym cenione u światowca zalety: „miłe usposobienie, piękny umysł, uprzejmość, gracja w obejściu oraz dyspozycja do brania udziału w ćwiczeniach i rozrywkach odpowiednich dla ludzi wysoko urodzonych" (s. 3). To, co zwraca uwagę w opisie bohatera, to jego całkowita integracja z otoczeniem - dobrze funkcjonuje wśród sobie równych, potrafi zjednywać sympatie i zawierać odpowiednie sojusze. Dwór jest naturalnym i jedynie znanym środowiskiem Fulgencia. Jego zachowanie w żaden sposób nie odbiega od panujących tam zwyczajów - Fulgencio nie wyróżnia się ani w wyborze rozrywek, ani zajęć intelektualnych czy sportowych, nie kwestionuje panujących reguł czy obowiązujących norm postępowania. Jak ukaże dalszy ciąg historii, do normy tej należała również daleko posunięta swoboda seksualna.

Camus przedstawia zarówno fakt dorastania na dworze, jak i opuszczenia go jako naturalną pochodną wysokiej pozycji społecznej bohatera. Dla arystokraty pragnącego zapewnić sobie łaski monarchy przebywanie w jego najbliższym otoczeniu ma pierwszoplanowe znaczenie. Dwór to miejsce dla wybrańców, ale także „teatr próżności tego świata” (s. 6) ${ }^{16}$, w którym rządzą pozory i sztuczne wartości. Biskup Belley nie kwestionuje konieczności przynależenia do królewskiej świty, ukazuje jednak, że jest to środowisko wykształcające w ludziach nawyki i oczekiwania, które łatwo mogą doprowadzić do lekceważenia norm moralnych i religijnych.

Po osiągnięciu dojrzałości i zabezpieczeniu swej pozycji strategicznie zawiązanymi sojuszami Fulgencio musi wrócić do domu w Katalonii, by przejąć obowiązki głowy rodu. Jest panem samego siebie, jego wola nie ma żadnych ograniczeń. Jednak nie czerpie satysfakcji z tego stanu rzeczy, gdyż po opuszczeniu Madrytu znalazł się w towarzyskiej pustce - nikt na prowincji nie dorównuje mu pozycją, jedynym towarzyszem jest młodszy brat.

René Pintard, opisując libertynizm francuski pierwszej połowy XVII w., tak zdefiniował to pojęcie: „Libertyńskim jest każde zachowanie, które cechuje nadmiar swobody w podejściu do zasad moralności i religii, określonych przez zwy-

16 Raymond Trousson, opisując środowisko francuskich mondains, również stwierdza, że przypominało ono teatr, w którym postaci cały czas miały świadomość, że są przez innych obserwowane i oceniane. Zob. R. Trousson (dir.), Romans libertins du XVIII siècle, Laffont, Paris 1993, s. XXVIII. 
czaj, dogmat, tradycję oraz władzę"17. Camus w Palombe zadaje zasadnicze pytanie: co sprawia, że człowiek przekracza granicę dozwolonych norm, staje się libertynem? Odpowiada na nie, ukazując, jak wielkim wyzwaniem jest konieczność zmierzenia się z nową, obcą rzeczywistością.

Nieśpieszny rytm prowincji wkrótce zaczyna nudzić hrabiego, przyzwyczajonego do pełnego podniet i rozrywek życia dworu ${ }^{18}$. Uprzejmie obcuje z miejscowymi elitami, ale ma przekonanie o własnej wyższości. Fulgencio, który „aż za dobrze wyćwiczył się w Madrycie w sztuce prawienia duserów, flirtowania i pieszczot" (s. 6), żadnej z panien czy dam nie uznaje za wystarczająco interesującą, co dodatkowo potęguje jego poczucie niedosytu. Dopiero poznanie Palombe, pięknej i cnotliwej panny wysokiego rodu, wyrywa go z nudy. Zdobycie ręki dziewczyny wymaga przełamania zdecydowanego oporu jej matki. Ta przeszkoda czyni z zalotów wyzwanie, które Fulgencio z zapałem podejmuje. Zręczne intrygi, w których musi zmierzyć się z otoczeniem, to jego żywioł. Wykorzystuje bez skrupułów swoją pozycję, przemyślnie obchodzi sprzeciw matki, uzyskując aprobatę dalszych krewnych i, co najważniejsze, zgodę króla na małżeństwo. Umiejętność uwodzenia sprawia, że zdobywa nie tylko rękę, ale i serce wybranki.

Sto lat przed Crébillonem, Laclosem czy Sadem Camus ukazuje, że libertyn to łowca, zbierający podboje miłosne jak trofea, dla którego egzystencja nabiera sensu wraz z pojawieniem się zdobyczy ${ }^{19}$. Przy tym najważniejszy jest sam proces zdobywania kobiety, wyzwanie, jakie stanowi przełamywanie jej oporu ${ }^{20}$. Dlatego zwykle skonsumowanie związku jest początkiem jego końca. Jednak w odróżnieniu od wymienionych pisarzy, którzy w braku stałości w uczuciach i nieustannym zdobywaniu wciąż nowych serc widzieli efekt presji społeczności mondains ${ }^{21}$, zdaniem Camusa wpojona na dworze rozwiązłość przechodzi w nawyk i nie ustaje, gdy owa presja zanika.

Namiętna miłość do Palombe, którą deklarował Fulgencio, trwała zaledwie dzień. Nazajutrz po weselu hrabia urządził corridę, podczas której w dramatycznych okolicznościach spotkał młodą szlachciankę Glafirę i zakochał się w niej. Jest to kluczowy moment intrygi, wprowadzający główny wątek powieści - stanowią go

\footnotetext{
17 R. Pintard, Le Libertinage érudit dans la première moitié du XVIle siècle, Slatkine, Genève 2000, s. XIV.

18 Nuda jako jedna z głównych przyczyn rozwiązłego trybu życia francuskich mondains będzie stałym motywem XVIII-wiecznych powieści libertyńskich. Zob. D. Hölzle, Le Roman libertin au XVIIle siècle: une esthétique de la séduction, Voltaire Foundation, Oxford 2012, s. 43.

19 Specyficzne zjawisko XVIII-wiecznego libertynizmu francuskiego opisane zostało wyczerpująco m.in. w następujących pracach: C. Cazenobe, Le Système du libertinage de Crébillon à Laclos, Voltaire Foundation, Oxford 1991; A. Siemek, La recherche morale et esthétique dans le roman de Crébillon fils, The Voltaire Foundation, Oxford 1981; R. Trousson (dir.), op. cit.; A. Viala, La France galante, PUF, Paris 2008.

20 Por. G. Vincent, Formes sociales et formes d'historicité, Publibook, Paris 2010, s. 307-309.

21 Pisze o tym m.in. Bernadette Fort w monografii Le Langage de l'ambiguïté dans l'œuvre de Crébillon fils, Editions Klincksieck, Paris 1978, s. 202.
} 
cierpienia libertyna, rozdartego pomiędzy egoistycznymi pragnieniami i nawykami a obowiązującymi chrześcijanina normami moralnymi.

Powieść Camusa koncentruje się na tej dramatycznej sytuacji. Owładnięty namiętnością hrabia zamyka się w sobie, staje milczący, w stosunku do żony zachowuje poprawnie, wypełnia obowiązki małżeńskie, ale robi to niechętnie. Całkowicie skoncentrowany na sobie, nie jest w stanie zaakceptować sytuacji, w której, jako człowiek żonaty, powinien przestrzegać monogamii. Nawykły do swobody seksualnej i częstej zmiany przedmiotu uczuć, na prowincji postępuje tak jak w stolicy - stara się zdobyć wzajemność Glafiry. Stwierdza bez poczucia winy: „jestem dworzaninem, i to z królewskiego dworu, dla którego czystość obyczajów i wstrzemięźliwość jest czymś w rodzaju feniksa” (s. 251). I dodaje: „dworzanie nieustannie starają się umilać sobie czas z różnymi napotykanymi w towarzystwie damami” (s. 229-230).

Ostatecznie Fulgencio wyznaje Glafirze miłość oraz proponuje konkubinat. Ta, przerażona, ucieka nocą i chroni się w klasztorze. Hrabia po odkryciu jej nieobecności wpada we wściekłość, oskarża niesłusznie żonę o pomaganie rywalce i oddala ją z pałacu do jednej ze swoich posiadłości. Obojętny na głosy otoczenia wzywające go do opamiętania, popada w rodzaj manii prześladowczej. Izoluje się od świata, głuchy na rady przyjaciół, namawiających go do pogodzenia się z żoną. Dopiero po kilku miesiącach lektura pliku listów Palombe, w których zapewnia męża o swym oddaniu i miłości, burzy zacięty upór Fulgencia, doprowadza go do katharsis, którego efektem jest wygaśnięcie namiętności do Glafiry i pełne pojednanie z małżonką.

Degrengolada moralna Fulgencia po zakochaniu się w Glafirze barwnie i przekonująco ukazana została przez Camusa jako efekt jego nieprzystosowania do nowych warunków życia. Po ślubie libertyńskie skłonności powinny zostać wygaszone, jednak pisarz ukazuje, że nie jest to proces szybki i bezbolesny. Główny bohater znalazł się w emocjonalnej pułapce - powinien być kochającym i oddanym mężem, jednak jego miłość do żony okazała się nietrwała. Ponadto konieczność zachowania pozorów wierności oraz opór nowej wybranki sprawiają, że hrabia jest, paradoksalnie, zarazem wierny i niewierny ${ }^{22}$. Ta sytuacja dorowadza go na skraj szaleństwa, z którego uratuje go dopiero cnotliwa i wierna żona.

Camus nie piętnuje ex katedra głównego bohatera, lecz stara się wyjaśnić czytelnikom, dlaczego zdarzają się w ich życiu cudzołóstwo, związki pozamałżeńskie czy choćby tylko napięcia istniejące między związkiem oficjalnym, w którym są związani przysięgą małżeńską, a związkiem nieoficjalnym, do którego popycha ich namiętność.

22 Jean Michel Pelous trafnie opisuje puste uczuciowo relacje, które libertyni nawiązywali ze swoimi wybrankami jako „miłość bez miłości, czyli antymiłość” (tłum. własne - M.P.); J.-M. Pelous, Amour précieux, Amour galant (1654-1675), Klincksieck, Paris 1980, s. 155. 
Dyskutując z jednym z przyjaciół o miłości, Fulgencio podaje powód zaniku uczuć do żony:

[Palombe] jest moją żoną. Kocham ją tak, jak nakazuje mi obowiązek, ale nie ma nic gorszego niż kochać z obowiązku. W miłości zobowiązanie wprowadza skrępowanie, a przymus unicestwia ją. Kochałem [Palombe] namiętnie przed ślubem, po ślubie płomień mej miłości zamienił się w lód. Wierzę, że jeśli chce się przestać kochać kobietę, to najlepszym sposobem jest ją poślubić. Małżeństwo leczy z miłości, święte więzy gaszą ja. (s. 239)

Bohater utożsamia swobodę erotyczną z wolnością osobistą, a przejście ze stanu kawalerskiego do małżeńskiego wiąże się z wyrzeczeniem tej wartości. Efektem jest głęboka trauma i żal do świata. Czytelnicy mondains z pewnością odnajdywali echo własnych dylematów w słowach Fulgencia, wyznającego, że:

Kontrakt małżeński jest podobny klatce, do której ptaki fruwające wolno chcą wejść, a te, które już tam są, desperacko próbują się z niej uwolnić. Ale tak, jak jedynym wejściem jest kościelna brama, tak wyjściem jest grób. (s. 145)

Camus, zręcznie, nie neguje poglądu o utracie wolności po zawarciu małżeństwa, ale jednocześnie ukazuje, że pogoń za wolnością to nierealna mrzonka. Żaden człowiek żyjący w społeczeństwie nie jest wolny, a szczególnie zależni od kaprysu władcy czy norm etykiety mondains: „Czyż są ludzie mniej wolni i bardziej niewolnikom podobni niż dworacy? Ich kajdany są złote, ale to zawsze kajdany" (s. 244-245). Rozpusta jest tylko pozornym wyrazem wolności, a w swojej istocie nie tylko jej nie zapewnia, lecz wręcz szkodzi wizerunkowi, upadla człowieka. Libertyn arystokrata traci szacunek otoczenia, gdyż nie dorósł do godnego wypełnia ciążących na nim obowiązków społecznych:

Czy myślicie, iż przyjemnie jest oglądać szlachetnego kawalera, wielkiego pana, osobę wysoko urodzoną, predysponowaną do tego, by służyć przykładem i być wzorem dla otoczenia, goniącego za tymi zwierzęcymi przyjemnościami? Czy sądzicie, że dworzanin, który ma zaszczyt oglądać codziennie wielkiego władcę i przebywać w świętym pałacu królewskim, którego nic nie powinno zbrukać, dobrze robi, oddając się przez całą noc niegodnym rozkoszom? (s. 230)

Wysokie urodzenie nie gwarantuje szacunku na dworze, każdy może stracić reputację, postępując niegodnie ${ }^{23}$. Dlatego tak ważna jest umiejętność samokontroli.

Unikając tradycyjnej kaznodziejskiej retoryki, straszącej rozpustników ogniem piekielnym, biskup Belley odwołuje się w swojej argumentacji do kodeksu etyczne-

23 Opisując francuskie społeczeństwo dworskie, Norbert Elias stwierdza: „Każdy zależy od każdego, wszyscy zależą od króla. [...] Osoba, która wczoraj zajmowała najwyższą pozycję, mogła ją następnego dnia utracić" (tłum. własne - M.P.); N. Elias, La société de cour, Calman-Lévy, Paris 1974, s. 98. 
go środowiska mondains. W hierarchii dworskiej najwyżej ceniono honor i związane z nim przekonanie, że arystokraci są grupą godną naśladowania, lepszą moralnie od gminu. Nie polemizując z tym założeniem, Camus ukazuje, że libertyn rozpustnym postępowaniem sam rezygnuje z prerogatyw swojego stanu. Używając obrazowego sformułowania: sam schodzi z piedestału, na który wyniosło go urodzenie. Szacunek otoczenia nie jest bezwzględny - można go stracić, zachowując się niehonorowo. To ostrzeżenie musiało trafiać dworzanom do przekonania.

Pisarz nie obraża czytelników mondains, nie ukazuje ich jako ludzi niegodnych czy bezbożnych, tylko jako nieroztropnych, niedostrzegających świata istniejącego poza wąskim kręgiem dworu i niepotrafiących przewidywać negatywnych konsekwencji swawolnego trybu życia. Szacunek otoczenia poza murami pałacu królewskiego zdobywa się szlachetnym i odpowiedzialnym postępowaniem. Tę prawdę czytelnicy powinni sobie przyswoić.

Camus przedstawia w Palombe portret młodego człowieka, zdeprawowanego przez środowisko, w którym się wychował, ale przede wszystkim kreśli wizerunek osoby niedojrzałej, bezrefleksyjnie przyjmującej normy zachowania otoczenia, goniącej za ułudą nieskrępowanej wolności, utożsamianej z podbojami sercowymi. Mondains tworzą specyficzny mikrokosmos, funkcjonujący jedynie w stolicy. Fulgencio cierpi z powodu więzów małżeńskich tak długo, dopóki nie zrozumie, że wolność to mrzonka, a jego wysoka pozycja społeczna to nie tylko splendor i przyjemności, ale przede wszystkim obowiązki względem rodziny i poddanych. Szczera miłość, którą ofiarowuje mężowi Palombe, uświadamia mu, czym powinno być uczucie. Wyrzeczenie się libertynizmu to odrzucenie egoistycznego nawyku towcy na rzecz bezwarunkowej, bezinteresownej więzi. Tę prawdę Fulgencio dostrzega dopiero, gdy przestaje skupiać się wyłącznie na sobie. Portret libertyna stworzony przez Camusa w Palombe nie przeraża, ale jest przestrogą dla środowiska dworskiego. Przede wszystkim jednak udowadnia, że libertynizm nie jest nawykiem nie do opanowania, daje nadzieję tym, którzy pragną odmienić swoje życie.

\section{Bibliografia}

Bertrand D., Pourquoi et comment les jésuites ont pris en charge l'enseignement en Europe, w: B. Pinchard, P. Servet (red.), Education, transmission, rénovation à la Renaissance, Droz, Genève 2006.

Camus J.-P., Palombe, ou la femme honorable, Histoire catalane, C. Chappelet, Paris 1625, www.gallica.bnf.fr [dostęp : 10.05.2018].

Cazenobe C., Le Système du libertinage de Crébillon à Laclos, Voltaire Foundation, Oxford 1991.

Elias N., La société de cour, Calman-Lévy, Paris 1974.

Fort B., Le Langage de l'ambiguïté dans l'œuvre de Crébillon fils, Editions Klincksieck, Paris 1978.

Hölzle D., Le Roman libertin au XVIIle siècle : une esthétique de la séduction, Voltaire Foundation, Oxford 2012. 


\section{VARIA}

Maja Pawłowska

Lever M., Au seuil du XVIIe siècle, „Littératures Classiques” 1991, nr 15.

Magendie M., La politesse mondaine et les théories de l'honnêteté, en France au XVII siècle, de 1600 à 1660, t. 1, Slatkine reprints, Genève 1993.

Mousnier R., Etudes sur la population de la France au XVIle siècle, „Le XVII siècle” 1952, nr 16.

Pawłowska M., Mimesis a teorie siedemnastowiecznej powieści francuskiej, Wydawnictwo Uniwersytetu Wrocławskiego, Wrocław 2011.

Pelous J.-M., Amour précieux, Amour galant (1654-1675), Klincksieck, Paris 1980.

Perrault C., Les Hommes illustres qui ont paru en France pendant ce siècle, M. Rogguet, La Haye 1698.

Pessel A., L'«Essay sceptique» de Jean-Pierre Camus, „Les Études Philosophiques” 2008, nr 85.

Pintard R., Le Libertinage érudit dans la première moitié du XVIle siècle, Slatkine, Genève 2000.

Robic-de Baecque S., Romans et dévotion au XVIIe siècle, „Littératures Classiques” 2000, nr 39.

Robic-de Baecque S., Le Salut par l'excès. Jean-Pierre Camus (1584-1652), la poétique d'un évêque romancier, Champion, Paris 1999.

Sales F. de, Introduction à la vie dévote, P. Rigaud, Lyon 1609.

Siemek A., La recherche morale et esthétique dans le roman de Crébillon fils, The Voltaire Foundation, Oxford 1981.

Trousson R. (dir.), Romans libertins du XVIII' siècle, Laffont, Paris 1993.

Viala A., La France galante, PUF, Paris 2008.

Vincent G., Formes sociales et formes d'historicité, Publibook, Paris 2010. 